\title{
Design of Energy Management System Base on lithium-ion Battery
}

\author{
Yusuf Bello Saleh $^{1 *}$, Hasan Kürüm ${ }^{2}$ \\ $\mathbf{1}^{*}$ Division of Agricultural Colleges, Ahmadu Bello University Zaria, Nigeria, (ORCID: 0000-0002-9746-0497), yusufbellosaleh@gmail.com \\ ${ }^{2}$ Department of Electrical and Electronic Engineering, Firat University, Turkey, (ORCID: 0000-0002-5498-6819)
}

(1st International Conference on Applied Engineering and Natural Sciences ICAENS 2021, November 1-3, 2021)

(DOI: 10.31590/ejosat.1013311)

\begin{abstract}
ATIF/REFERENCE: Umut Özkaya, Konya Technical University, Şaban Öztürk, Amasya University. (2021). Design of Energy
\end{abstract} Management System Base on lithium-ion Battery. European Journal of Science and Technology, (28). 1144-1151.

\begin{abstract}
In today's world, green energy is becoming increasingly important. Due to air pollution, electric vehicles are currently the greatest option for the environment, personal and public transportation. Electric vehicles need batteries, which might be hazardous if they are not used in a safe atmosphere. The purpose of this work is to develop a battery management system (BMS) prototype that can track the voltages, currents, and cell balancing of each cell in a battery pack, as well as the temperature of the pack. The batteries in electric vehicles must always be kept under control within their operational safety area (SOA). To achieve the desired voltage and capacity, multiple battery cells are joined. A huge number of cells are necessary to provide the high voltage and capacity required for electric vehicles. This paper developed methods for monitoring each battery cell's functionality and Algorithms for detecting bad cells for replacement in the battery pack and displaying those cells condition on the monitor whether they are good or bad to notify the users, the current conditions of each cell for the user's next line of action. The experiment was carried out using STM32 microcontrollers.
\end{abstract}

Keywords: Battery pack, cell balancing, Temperature measurement, Current Measurement, voltage Measurement.

\section{Lityum İyon Bataryaya Dayalı Enerji Yönetim Sistemi Tasarımı}

\section{$\ddot{O} z$}

Yeşil enerjiyi kullanmak günümüz dünyasında giderek daha önemli hale gelmektedir. Hava kirliliği nedeniyle elektrikli araçlar şu anda çevre, kişisel ve toplu taşıma için en iyi seçimdir. Elektrikli araçlarda kullanılan piller, güvenli bir çalışma alanında kullanılmadıkları takdirde tehlikeli olabilir. Bu çalışmanın amacı, pil paketindeki her hücrenin gerilimini, akımını, hücre dengelemeyi ve paketin sıcaklığını izleyebilen bir batarya yönetim sistemi (BYS) tasarlamaktır. Bunun için, sistemin donanımını ve işleyişini değerlendirmek amacıyla sistemin örnek bir test bileşeninin geliştirilmesi gerekir. Elektrikli araçların, güvenlikleri operasyonel alan (GOA) içerisinde her zaman kontrol altında tutulmalıdır. İstenen gerilim ve kapasiteyi elde etmek için birden fazla pil hücresi birleştirilir. Elektrikli arabalar için gereken yüksek gerilim ve kapasiteye ulaşmak için çok sayıda hücreye ihtiyaç vardır. Bu tezde, her bir pil hücresinin işlevini izleyerek kötü hücreleri tespit etmek ve bu hücreleri pil paketinde değiştirmek üzere bir algoritma geliştirilmiştir. Bu hücrelerin durumu LCD ekranda gözlenmiştir.

Anahtar Kelimeler: Batarya paketi, Hücre dengeleme, Sıcaklık ölçümü, Mevcut ölçüm, voltaj ölçümü

\footnotetext{
* Corresponding Author: yusufbellosaleh@gmail.com
} 


\section{Introduction}

The most air pollution and combustion engines in the world are caused by ground emissions. Furthermore, traditional vehicles (fuel) account for $25 \%$ of $\mathrm{CO}_{2}$ emissions and air pollution in the atmosphere. The number of people driving private and public vehicles is increasing, as is air pollution. As a result, electric vehicles are becoming more popular. Electric vehicles are not new to the world, but technological advancements and rising pollution concerns have branded them as the mobility of the future. In addition to the electric motor, the key component of the electric vehicle $(\mathrm{EV})$ is the battery, which replaces internal combustion engines. The rapid progress of power electronics and control systems has cleared the way for a wide range of electric cars to be used. The major purpose of this work was to build a more efficient battery management and control system for use in EV. The basic components of an electric car are as follows: When employing lithium-ion batteries, the BMS, electric motor, motor control, DCDC converter, EV battery charger, cable system, regenerative brake system, vehicle body, and chassis are all crucial factors. Any electrical system that controls a rechargeable battery by preventing it from functioning outside its SOA and monitoring its state of charge, temperature, voltage, and current is known as a BMS. The batteries of an electric vehicle should always be kept under control. By combining more than one cell in the battery cells, the desired voltage level and energy are generated. To attain the necessary high voltage and energy for electric vehicles, numerous cells are required. To monitor each cell, BMS are required. Measure the voltage and temperature of a cell.

\section{Material and Method}

\subsection{Method}

Technology has advanced to the point where stand-alone devices such as microcontrollers may now execute all needed functions without the use of extra hardware. Advanced microcontrollers have evolved into microcomputers, sometimes known as single board computers. These devices are controlled by powerful microcontrollers. These microcontrollers include a large number of integrated circuits on board, allowing them to do a variety of tasks on their own(Y1lmaz GÜVEN, 2017). The microcontroller chosen was the STM32F103C8; the microcontroller's functioning is reliant on a minimal number of external components. In this research, the microcontroller's various pins were arranged for communication with external components. The ADC pins and CAN buses of the STM32F103C8 are used to connect to external hardware. This microcontroller has an ARM-based 32-bit MCU with a mediumdensity performance line, USB, 7 timers, 2 ADCs channels, 64 or 128 KB Flash memory, CAN, and 9 communication connectors. The temperature measurement circuit, Voltage monitoring circuit, current monitoring circuit, balancing circuit and CAN bus are all connected to the microcontroller as shown in the general circuit block diagram in figure 1.

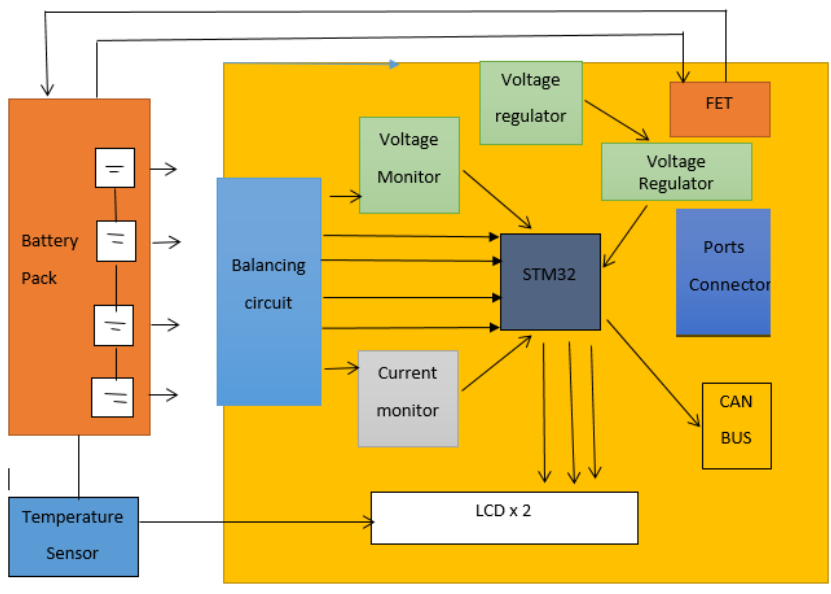

Figure 1: General circuit block diagram

This microcontroller is program by using keil IDE $\mu$ vision5. The Negative temperature coefficient (NTC) thermistor temperature sensor is crucial in the measurement and safety of a Li-Ion battery. They provide critical temperature information to help Li-Ion batteries work optimally during the charging process. The charging pace slows down if the battery temperature is too low, and it becomes dangerous if the battery temperature is too high. Maintaining the proper charging temperature range also extends the life of the battery(Raijmakers, Danilov, Eichel, \& Notten, 2019). NTC has been monitored the temperature of the battery pack in this research. So, in the battery pack, a thermistor NTC was added in series to each battery cell to monitor the temperature of each cell. We chose to use a 10k thermistor as a variable a resistor connected in series to a fixed resistor of the same value $10 \mathrm{k}$ to form a voltage divider and then take that the voltage at the middle to the ADC pins of the STM32 and convert it to a temperature the circuit connection as shown in figure 2, that temperature will be displayed on the LCD using the Steinhart equation.

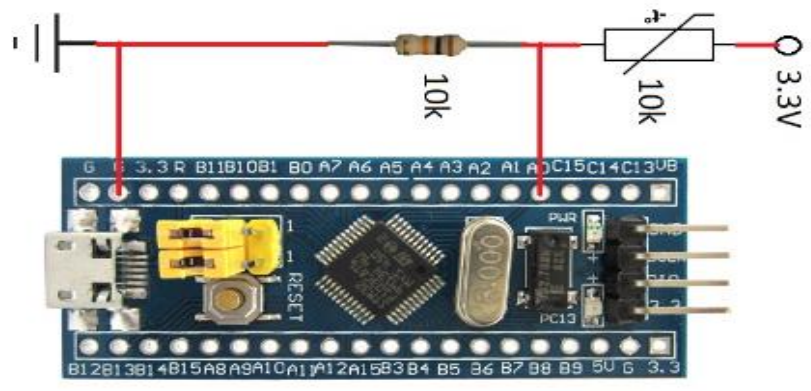

Figure 2: Temperature measurement circuit connction using NTC

Calculating the voltages of individual cells in a series-connected battery is difficult Because the reference point remains constant in the circuit. Assume that the four cells are all at $4.2 \mathrm{~V}$ and thus lighter. When testing the cell voltage with a microcontroller such as the STM32, this can make it easier to measure the voltage of the first cell because the other end is connected to ground. Other cells, on the other hand, must be measured in relation to the voltage of the previous cell; for example, when calculating the voltage of the fourth cell, the voltage of all four cells must be measured simultaneously(Carriero). This is a problem because the reference point cannot be moved. As a result, more circuits must be built with the help of specific voltage calculations. The simplest method is to use a potential divider to map the voltage 
levels and then compute them; however, this research will improve the read value resolution to more than $0.1 \mathrm{~V}$. When used as a differential amplifier, Op-Amp returns the difference between the two voltage values applied to its inverter and non-inverter pins(Stuart \& Zhu, 2011). Two optional differential amplifiers OPA4197 are required to measure the voltage of four cells the voltage result of the four cell is displayed on the LCD monitor. Figure 3 show the entire circuit diagram for multicell voltage measurements in a lithium battery pack using OPA4197.

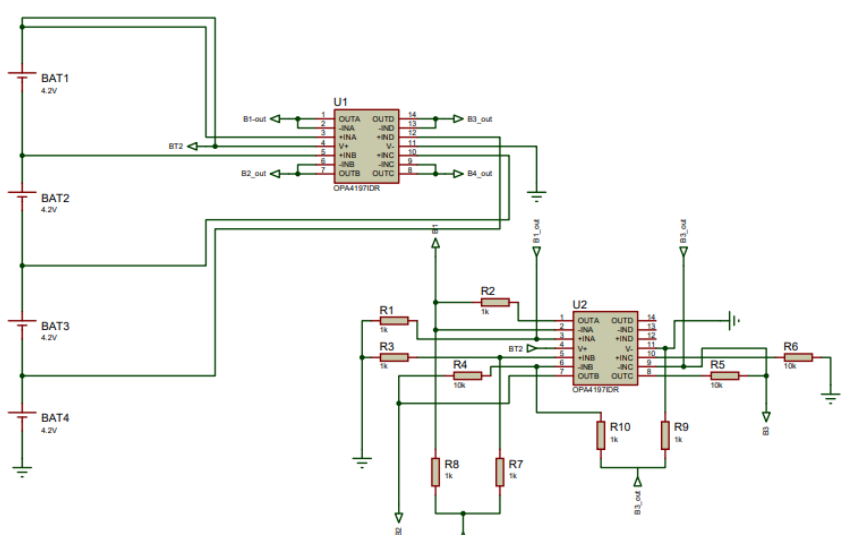

Figure 3: Multi cell voltage measurement uisng OPA4197 Opamp

Current sensing has long been a key feature of battery management systems (BMS), which track and protect large batteries. Current measurements are used in both lithium-ion and sealed lead-acid batteries to safeguard the battery from abuse and ensure its safe operation by allowing for emergency shut-down in over-current situations. For security and safety functions alone, the accuracy of existing measurements can be quite inadequate(Do Valle, Wentz, \& Sarpeshkar, 2011). The device designer should specify over-current circumstances conservatively such that the safe shut-down threshold is not passed, even if the existing sensor significantly underestimates it. However, in this work, we only consider the current sensing of each cell in order to show such currents on an LCD for user reference and to learn about the current states of the batteries. As a current sensor, the LM358P operational amplifier was employed. Existing sensing requirements, on the other hand, are becoming even more severe in some applications. Electric car manufacturers, in particular, are working hard to increase efficiency and attract users to their vehicles. The LM358 noninverting terminal is connected to the middle of the load and shunt resistors, which form a voltage divider, the inverting terminal is connected to $4.7 \mathrm{~K}$, which is connected to ground, and feedback resistor $22 \mathrm{k} \Omega$ from the output of the $\mathrm{LM} 358$, then $0.1 \mathrm{uF}$ capacitor as filter. The circuit setup for current measurement is shown in figure 4 .
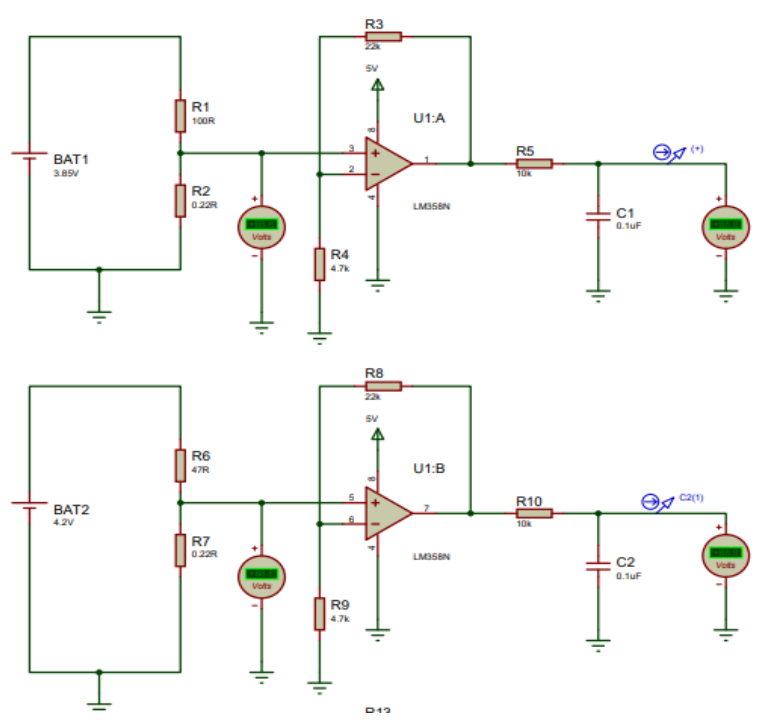

Figure 4: Current mesurements circuit

The cell balancing used in this research work is passive cell balancing because it is less expensive in terms of initial cost and space management(Neil Samaddar, 2020), as we are designing a prototype of battery management to come up with a design concept for the BMS. For the cell ON/OFF, a 2N7000 NPN MOSFET was used, and in laboratory practice, a 0.1 uf bypass capacitor and a 100R resistor were used to discharge the excess voltage and equalize it across the other cells. As protection against damage from the high voltage to the microcontroller, a $10 \mathrm{~K} \Omega$ resistor was used between the gate of the MOSFET and the input terminals of the STM32 microcontroller(Cao, 2008). The LED used is turned on to indicate which cell is currently charging and turned off to indicate which cell is fully charged. Figure 5 show the battery balancing setup.

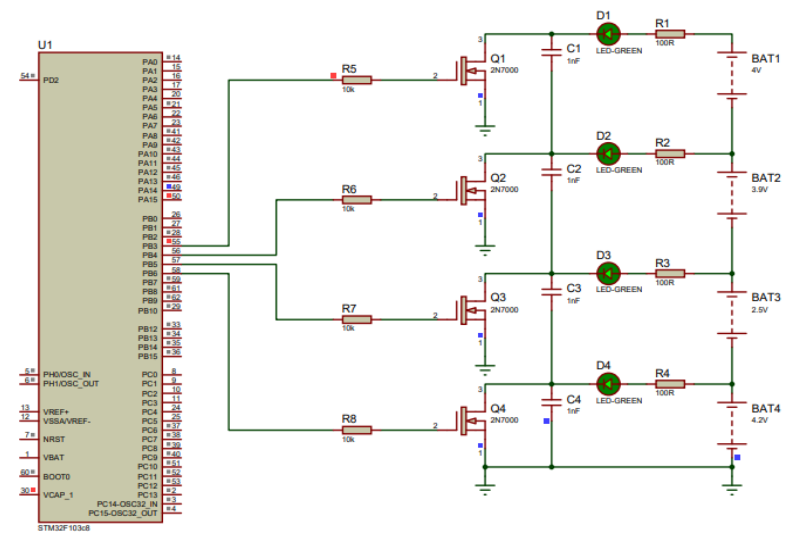

Figure 5: Battery balancing circuit

The charging and discharging circuit governs the charging and load of the battery pack, just like the battery control unit's electrical control unit in this study. Two MOSFETs, the IRF540 and the 2N6845, were used to control the charging and load processes, respectively. A diode was utilized to prevent the passage of energy from the battery to the charger, and two FETs were used to isolate and connect the battery between the charger and the load. The connection was made between the Q2 and Q3 MOSFETs, which control load and charge, respectively. The voltage Q3 is a monitor; if the charger is connected and the battery is disconnected from it, the current injected into the battery causes the voltage to rise to the charger's maximum supply voltage. which alerts the BMS to the availability of a charger to determine 
the charging connection, a current is injected into the load to see if there is a load, and then the Q3 driver is started. Figure 6 shown the charging and recharging circuit.

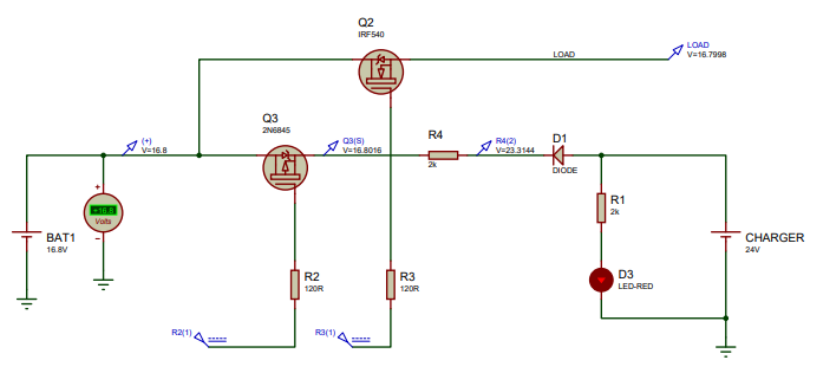

Figure 6: Charging and dsicharging circuit

The circuit components use $5 \mathrm{~V}$ and $3.3 \mathrm{~V}$, and voltage regulators 7805 and LM1117T were used to regulate the voltage to the desired voltage of the various circuit components, as shown in figure 7 .

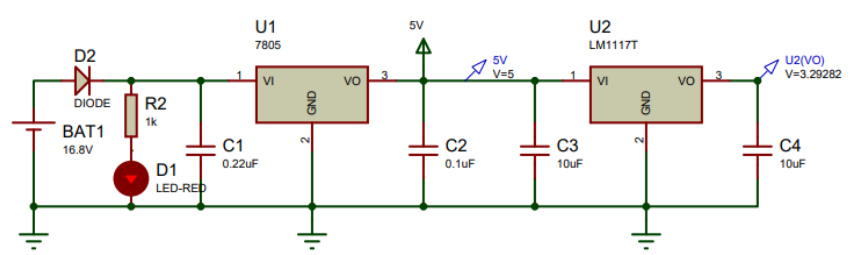

Figure 7: Voltage regulators connection

The circuit components use $5 \mathrm{~V}$ and $3.3 \mathrm{~V}$, and voltage regulators 7805 and LM1117T were used to regulate the voltage to the desired voltage of the various circuit components, as shown in figure 7. A $0.22 \mathrm{uF}$ capacitor was added to the input of the 7805 voltage regulator to help smooth out interruptions in the supply as well as law frequency distortion, and a $0.1 \mathrm{uF}$ capacitor was added to the regulator's output to filler the voltage. We used a $10 \mathrm{uF}$ capacitor for both the input and output of the LM1117T voltage regulator, as described by the manufacturer in the datasheet. A protection diode was added to the input side of the circuit to protect it if the power supply from the battery pack was connected incorrectly. We also added a $10 \mathrm{~K}$ resistor in series with a Red LED to detect the presence of a power supply in the circuit. The $5 \mathrm{~V}$ and $3.3 \mathrm{~V}$ are generated by the output of both regulators. Figure 8 show the experimental setup connection of the entire circuit duirng testing on the breadboard.

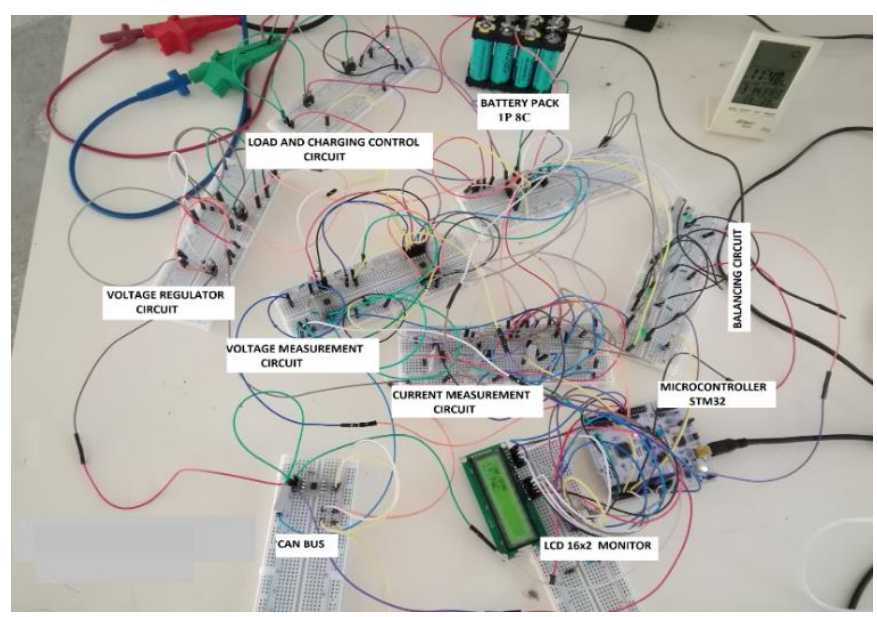

Figure 8: Laboratory experimental setup for general BMS circuit testing on breadboard

e-ISSN: 2148-2683

\subsubsection{The following equations are used for measuring thermistor resistance and Verification of the LM358P OP-Amp Output Voltage.}

Because resistors have a tolerance, the exact value of the fixed resistor and thermistor must be calculated for accurate temperature detection. The $9.95 \mathrm{k} \Omega$ value of the $10 \mathrm{k} \Omega$ fixed resistor was determined using a multimeter. To determine the actual resistance value of the $10 \mathrm{k} \Omega$ thermistor resistance (Rt), a connection was made on the breadboard at $24^{\circ} \mathrm{C}$. as shown in figure 9 .

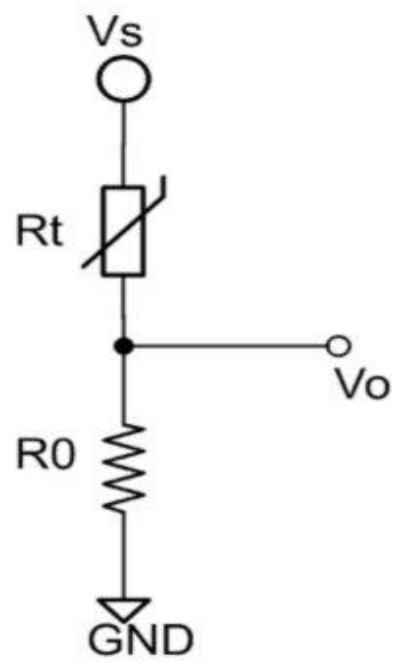

Figure 9: Thermistor resistance measurement circuit connection Supply voltage $(\mathrm{Vs})=3.3 \mathrm{~V}$

Fixed Resistance $($ Ro $)=9.95 \mathrm{~K} \Omega$;

Voltage divider $(\mathrm{Vo})=1.57 \mathrm{~V}$

Thermistor resistance $(\mathrm{Rt})=$ ?

$\mathrm{ADC}$ resolution $=12 \mathrm{bit}$

To find the actual value of the thermistor (Rt); we have to find the voltage value at point (Vo) by using Voltmeter.

$$
\begin{gathered}
V o=\frac{R o}{R o+R t} \\
R t=\frac{R(V s-V o)}{V o}
\end{gathered}
$$

By using equation 2 above

$$
\begin{gathered}
R t=\frac{9.95 k \Omega(3.3-1.57)}{1.57}=10.96 K \Omega \\
=10,960 \Omega \text { at } 24^{\circ} \mathrm{C}
\end{gathered}
$$

\subsubsection{ADC values}

$$
\begin{gathered}
A D C \text { Voltage }=\frac{V s}{A D C \text { bit }}=\frac{3.3 V}{2^{12}}=\frac{3.3}{4095} \\
=0.805 \mathrm{mV}
\end{gathered}
$$


$A D C$ Values $=\frac{\text { Vo }}{A D C \text { Valtage }}=\frac{1.57}{0.805 m v}=1950$

\subsubsection{Verification of the LM358P OP-Amp Output Voltage for current measurement.}

\section{Cell_1}

Load resistor $(\mathrm{RL})=47 \Omega$;

Shunt resistor $(\mathrm{RS})=0.22 \Omega$;

Feedback resistor $(\mathrm{Rf})=22 \mathrm{k} \Omega$;

In resistor $($ Rin $)=4.7 \mathrm{~K} \Omega$;

Voltage $(V)=4.2$ at fully charge;

Voltage drop (Vd) across the Shunt resistor (Rs);

$$
V d=\frac{(V * R s)}{\left(R_{L}+R s\right)}=\frac{(4.2 * 0.22)}{(47+0.22)}=\frac{0.924}{47.22}=0.195 \mathrm{~V}
$$

Load Current (IL)

$$
I_{L}=\frac{V}{R_{L}}=\frac{4.2}{47}=0.09 \mathrm{~A}
$$

$$
\text { Gain }=1+\left(\frac{R f}{\operatorname{Rin}}\right)=1+\frac{22 k \Omega}{4.7 k \Omega}=5.68
$$

Shunt resistor power rating

$$
P=I^{2} * R=(0.09)^{2} * 0.22=0.04 W
$$

The same procedure is taken for cell 2, 3 and 4 to make sure that the voltage each from the LM358P doest not exceed $5 \mathrm{~V}$ because to protect the microcontroller from damage the STM32 microcontroller operating volatge is $3.3 \mathrm{~V}$ to $5 \mathrm{~V}$.

\subsection{Material}

The lists of the components and materials used in this research shown in Table 1.

Table 1: List of the Materials used

\begin{tabular}{l|l|l}
\hline $\mathbf{S} / \mathbf{N}$ & Component & Quantity \\
\hline 1 & STM32F103C8 & 1 \\
\hline 2 & LM358P & 4 \\
\hline 3 & OPA4197 & 2 \\
\hline 4 & LCD 16x 2 & 1 \\
\hline 5 & Potentiometer & 1 \\
\hline 6 & LM1117T & 1 \\
\hline 7 & 7805 & 1 \\
\hline 8 & CAN tranceiver & 1 \\
\hline 9 & CAN Header & 1 \\
\hline 10 & Resistors & 30 \\
\hline 11 & Capacitors & 10 \\
\hline 12 & T block & 2 \\
\hline 13 & 2 N6845 & 1 \\
\hline 14 & IRF540 & 1 \\
\hline 15 & LED & 6 \\
\hline
\end{tabular}

\subsection{Algorithsm}

STM32cubeMx was used to configure the various pins utilized by various components in the system for BMS, and Keil ARM vision5 was used to program the system. The program is designed to control a four-cell lithium-ion battery cell module made up of eight batteries connected in parallel. The device continuously monitors the voltages of up to four lithium-ion battery cells. The microcontroller contains ten ADC channels, nine of which were used: four channels for voltage measurement, four channels for current measurements of the cells, and one channel for battery pack temperature monitoring. The microcontroller used four GPIO channels to control cell balancing, and the system also e-ISSN: 2148-2683 included a CAN and a Liquid Crystal Display (LCD). Stm32cubeMX is used to configure all of the microcontroller's pins, St-link utility is used to debug the code into the microcontroller, and Proteus Professional 8 was used to design the hardware circuit. The algorithm was created to check the voltages and currents of the cells, as well as to detect faulty cells and display them on the LCD to alert the user. 


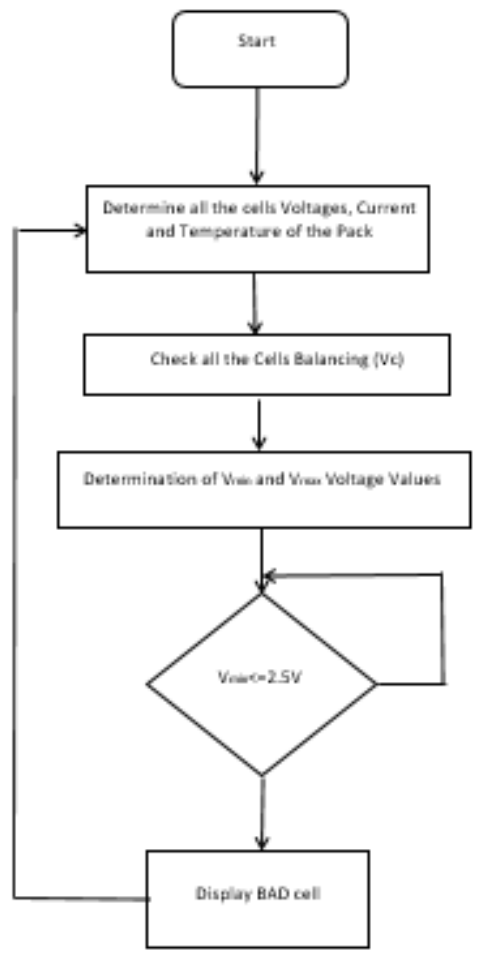

Figure 10: Flowchart Algorithsm

Figure 10. shows the flowchart algorithm used for cell balancing and fault detection of any cell that is faulty. Figure 11 and 12 is the PCB layout and 3D view of the BMS implimented respectively.

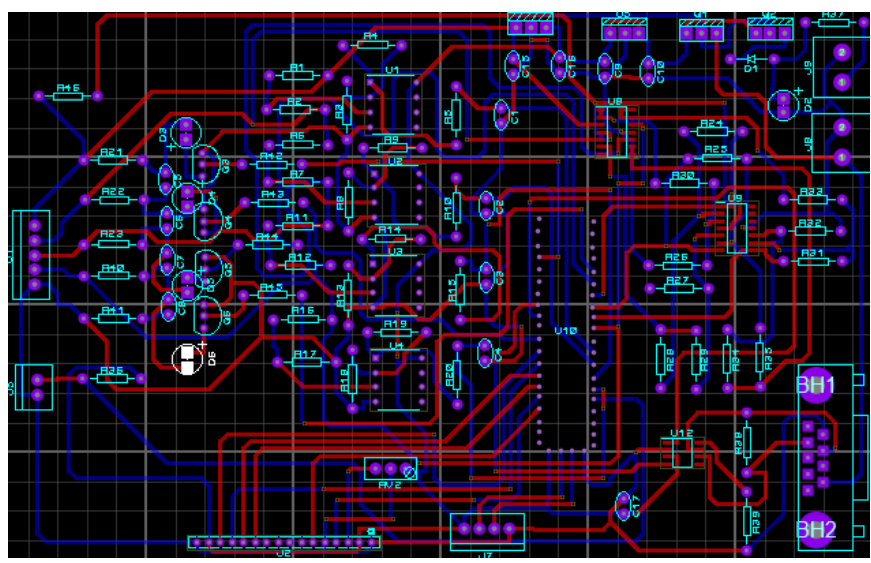

Figure 11: PCB layout

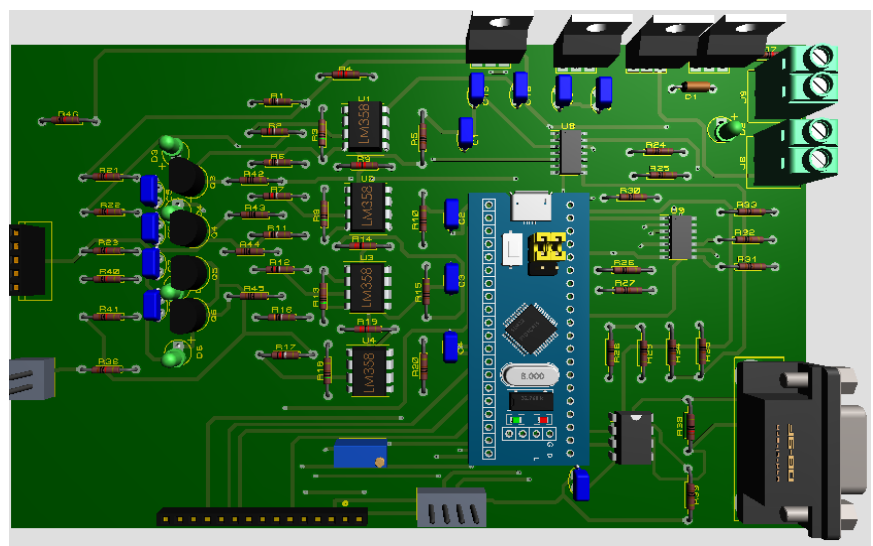

Figure 12: 3D view of the BMS

\section{Results and Discussion}

\subsection{Result}

The result obtained during the laboratory experiment showed the circuit is responding according to the design, the temperature is monitor during the experiment on the LCD and also the response of the temperature was also observed from STMstudio as shown in figure 13. The response of the individual cell voltage was equally seen in both the LCD and STMstudio which showed in figure 14. After the charging process of the battery, the batteries attained their maximum charged and the circuit balance the batteries to the same SOC as shown in figure 15. Also, the CAN bus transmission massage was also observed in the oscilloscope which was collected in a loopback made as shown in figure 16 . The completed laboratory implementation of the BMS final circuit shown in figure 17 and figure 18 BMS detected the Good and Bad Cells.

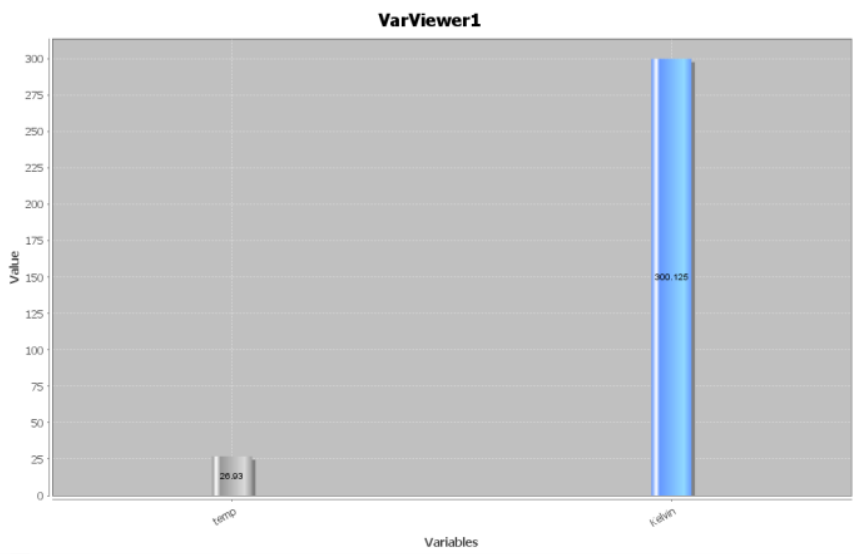

Figure 13: Temperature responce of the battery pack
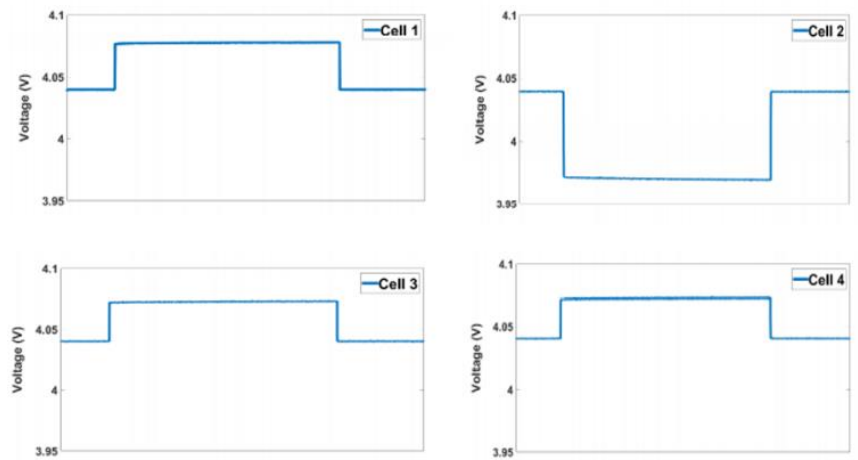

Figure 14: Individual cell voltages respond 


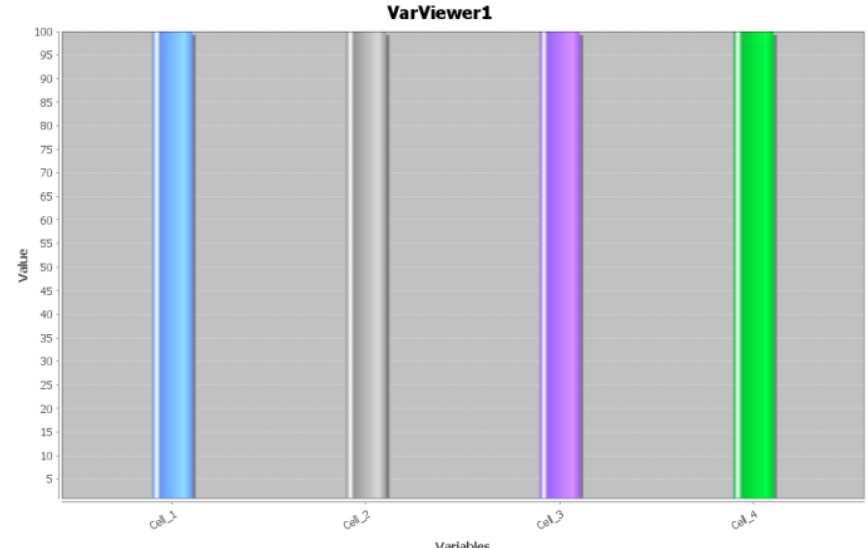

Figure 15: Voltages of the four lithium battery cells at their maximum full charge capacity $(100 \%)$

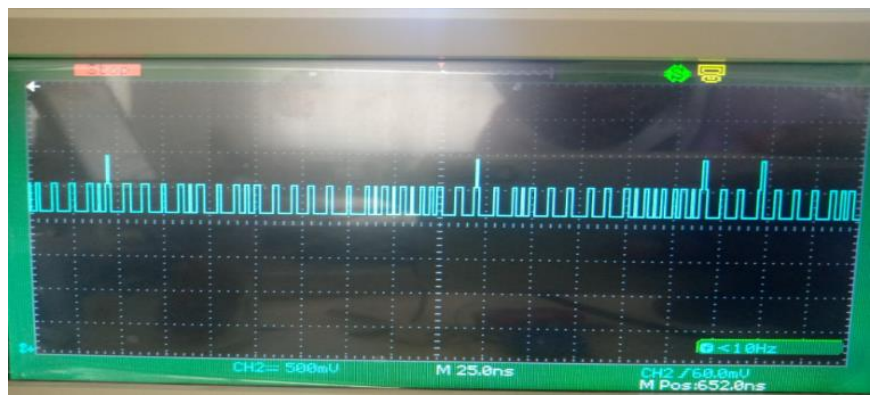

Figure 16: $\mathrm{CANH}$ transmission massage of the CAN bus

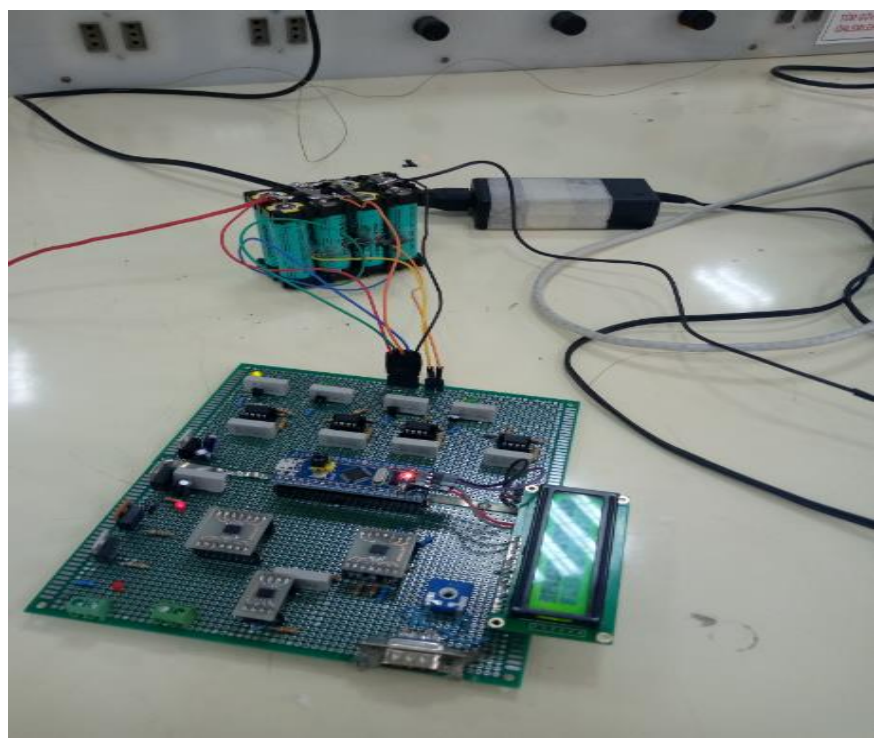

Figure 17: Completed laboratory implementation of the BMS final circuit

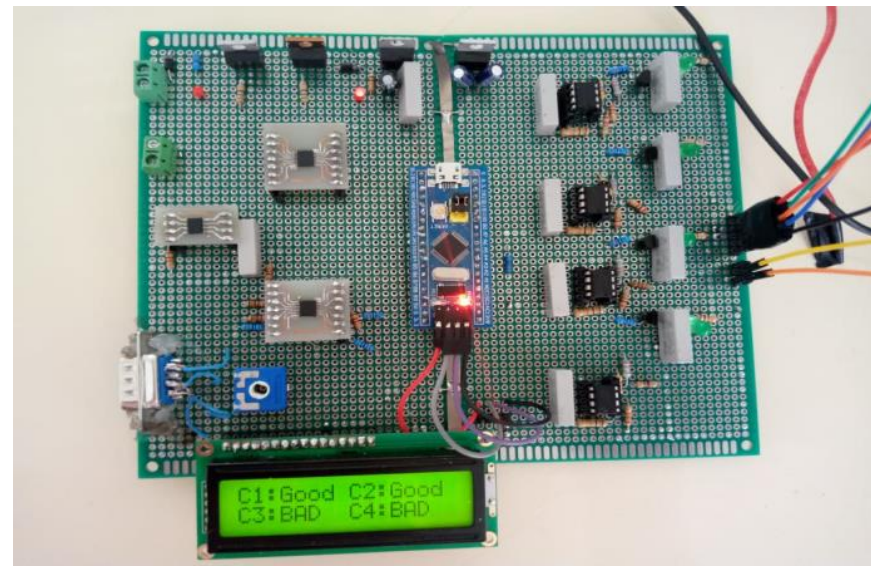

Figure 18: BMS detected the Good and Bad Cells

\subsection{Discussion}

The design of the Energy management system is the focus of this paper. Proteus 8 professional was used to create the circuit. The BMS design circuit in this paper consisted of numerous sections, including the power regulator circuit, current measurement circuit, voltage measurement circuit, CAN, temperature measurement, and balancing circuit. From figure 13 the temperature of the battery pack is observed both in celsius and kelvin this value was certified by the weather forecast monitor, the figure shows the individual voltage of the batteries from Stmstudio the same values was also observed on the LCD and Voltmeter. From figure 14 the voltage values of each of the four cells reach the same SOC at the same time that certifies the function of the balancing system and figure 15 shows the message transmitted from the can transceiver $\mathrm{CANH}$ which is connected in a loopback mode.

\section{Conclusions and Recommendations}

As part of this research, a BMS was built that can monitor the cell voltages and currents of each cell, as well as measure the temperature of the battery pack, as well as cell balancing, load and charge control, and an algorithm that can detect any problematic cells in the battery pack. To meet the specific needs of our system, the system architecture designed in this research is centralized architecture topology implemented. All of the system's components were designed and simulated in Proteus 8 professional, and they were also implemented on a breadboard to test their real-world performance before creating a prototype of the entire system. In this study, the Battery Management System is based on a lithium-ion battery $1 \mathrm{P} 8 \mathrm{C}$ with a capacity of $16.8 \mathrm{~V}$ as a prototype, and all of the system's components were evaluated in the lab and found to be functional. Load and charging control circuits, voltage, current, and temperature measurement, and cell balancing were all integrated together and created the full system in this research, which had a completed design and prototype manufacturing. The laboratory experimental outcome yields a good result that, designed prototype BMS system is functioning perfectly to power any system of its capacity, monitor the voltage, current, temperature and control the cell balancing.

The goal of this paper is to develop a concept for a battery monitoring system that can monitor voltages, current, temperature, and balance battery cells, as well as regulate load and 
charging control and detect any malfunctioning cells, in order to keep the battery within its safe operating range. According to the information I have gathered throughout this investigation, there is a need for a larger battery pack for use in electric vehicle operation, which necessitates the use of a significant number of battery cells depending on the capacity required. The microcontroller used in this research is the STM32, which has two $\mathrm{ADC}$ channels and ten ADC pins, nine of which were used for each of the four cells' current, voltage, and temperature. If this research work is to be used to any electric car battery storage in the future, a distributed design must be used, and microcontrollers with a higher number of $\mathrm{ADC}$ channels and $\mathrm{ADC}$ pins must be used to monitor currents, voltages, and temperature of each and every cell. When implementing on tiny power supply capacity EVs such bike motorcycles, two microcontrollers can be used as a slave and the other as a master via SPI.

\section{Acknowledge}

Specail thanks goes to Prof.Dr. Hasan KÜRÜM beside him Merve YILDIRIM deserves heartfelt gratitude for her important advice and encouragement. I would like to extend my special regards to my Mother Zuwaira Adam for her Constant prayers and Support all the time. I am indebted to my late father Alh. Bello Saleh who's passed away some years ago may his gentle soul rest in perfect peace. And also I thank all my family, friends, and colleagues for making me happy throughout our research period thank you all.

\section{References}

Cao, J., Schofield, N., and Emadi, A. (2008). Battery balancing methods: A comprehensive review. 2008 IEEE Vehicle Power and Propulsion Conference.

Carriero, C. Battery Stack Monitor Maximizes Performance of LiIon Batteries in Hybrid and Electric Vehicles.

Do Valle, B., Wentz, C. T., \& Sarpeshkar, R. (2011). An area and power-efficient analog Li-ion battery charger circuit. IEEE Transactions on Biomedical Circuits and Systems, 5(2), 131137.

Neil Samaddar, N. S. K., R Jayapragash. (2020). Passive Cell Balancing of Li-Ion batteries used for Automotive Applications. Journal of Physics: Conference Series.

Raijmakers, L., Danilov, D., Eichel, R.-A., \& Notten, P. (2019). A review on various temperature-indication methods for $\mathrm{Li}$-ion batteries. Applied energy, 240, 918-945.

Stuart, T. A., \& Zhu, W. (2011). Modularized battery management for large lithium ion cells. Journal of Power Sources, 196(1), 458-464.

Yılmaz GÜVEN, E. C., 3Sitk1 KOCAOĞLU 4Harun GEZICI,5Eray YILMAZLAR. (2017). Understanding the Concept of Microcontroller Based Systems To Choose The Best Hardware For Applications. International Journal of Engineering And Science, 6(9), PP -38-44 